\title{
Ethnic Difference in Brain Weight of 17-20 Year-Old Males in Northern Iran
}

\author{
Diferencias Étnicas en el Peso del Cerebro en Hombres \\ de 17 a 20 Años de Edad del Norte de Irán
}

Kamran Haidari"; Mehrdad Jahanshahi"*; Mohammad Jafar Golalipour ${ }^{* * * *}$

HAIDARI, K.; JAHANSHAHI, M. \& GOLALIPOUR, M. J. Ethnic difference in brain weight of 17-20 old males in Northern Iran. Int. J. Morphol., 34(3):986-989, 2016.

SUMMARY: Cranial capacity and brain weight are important measurements in the study of racial/ethnic differences. Using linear (Lee-Pearson's) formula, brain weight and cranial capacity were estimated in 398 normal 17 to 20-year-old males (200 native Fars and 198 Turkman) males in Northern Iran. The dimensions of the head measured with spreading caliper and auricular head spanner. The mean \pm S.D of brain weight and cranial capacity in native Fars males were $1343.45 \pm 102.37 \mathrm{~cm}^{3}$, and $1390.47 \pm 105.95 \mathrm{~g}$, and that of Turkmans were $1163.02 \pm 115.76 \mathrm{~cm}^{3}$ and $1203.73 \pm 119.81 \mathrm{~g}$, respectively. Cerebral Index was $3.40 \pm 0.37 \%$ and $2.52 \pm 0.37 \%$ in Native Fars and Turkmans, respectively and cerebral quotient was higher in Turkmans (8.34) than Native Fars males (7.95). This study showed, the effect of ethnic factor influences the brain weight of 17-20 year-old males in Northern Iran. Male; Iran.

KEY WORDS: Anthropometry; Cephalometry; Brain weight; Cranial capacity; Cerebral index; Cerebral quotient;

\section{INTRODUCTION}

The dimensions of the head and face are measured by Cephalometry which is one of the important tools in human anthropometry (Grau et al., 2001; El-Feghi et al., 2004).

These dimensions are affected by geographical, racial, ethnical, sex and age factors (Williams \& Bannister et al., 1995; Golalipour et al., 2003; Okupe et al., 1984; Irmak et al., 2004).

Cranial capacity which is in close correlation with brain volume reflects racial characteristics and thus has been thought to be one of the most common items in physical anthropological studies (Von Bonin, 1934; Hwang et al., 1995). The studies using different methods on the different samples reveal the same strong pattern. These methods apply measuring brain size using MRI, endocranial volume measured from empty skulls, wet brain weight at autopsy, and external head size measurements which all of them produce the same results (Dekaban, 1978; Peters et al., 2000;
Svennerholm et al., 1997; Mayhew \& Olsen., 1991; Cotter et al., 1999; Nooranipoor \& Masteri Farahani, 2008).

Regarding to the lack of documented studies and also the importance of acquiring information on brain weight in male living subjects in order to obtain baseline data, this study was carried out on living subjects to determine the linear dimensions of the heads measured by a classic cephalometry method as a baseline study for determining the brain weight and the effect of ethnic factor on normal 17-20 years-old males in Northern Iran.

\section{MATERIAL AND METHOD}

Three hundred ninety eight healthy $17-20$ years old males of Turkman group (200 native Fars 198 Turkmans) in Gorgan, South-East Caspian Sea border (North of Iran) were designated for this study.

\footnotetext{
* Assistant Professor, Medical Cellular and Molecular Research Center \& Department of Anatomical Sciences, Golestan University of Medical Sciences, Gorgan, Iran. ** Associated Professor, Department of Anatomical Sciences, Golestan University of Medical Sciences, Gorgan, Iran.

*** Professor, Gorgan Congenital Malformations Research Center, Department of Anatomical Sciences, Golestan University of Medical Sciences, Gorgan, Iran.
} 
Turkman population has been living in this area for more than two centuries, having immigrated from central Asia. They are exclusively marring in intra-group because of religious and ethnic beliefs so are a nearly pure ethnic group.

The native Fars group are the main and original inhabitants of the Gorgan region who had been selected from among the last three generations living in this area.

Body weight and height were determined in each case. Body weights were measured by spring weighingmachine (Soehnle, Germany) while the individual swearing light clothes, with an accuracy of $1 \mathrm{~kg}$ for weight and $1 \mathrm{~cm}$ for height.

At the same time in each individual the following linear dimensions of the head were measured:

1. Maximum head length (L) (Glabella inion length).

2. Maximum head breath (B) (measured between parietal eminences).

One and two parameters measured with a spreading caliper.

3. Auricular height (HT) (external acoustic meatus to the highest point of the vertex) using an auricular head spanner.

Each measurement was taken to the nearest millimeter at least three times and the average was considered for computation.

The cranial capacity was calculated using the following formula given by Williams \& Bannister et al., and Manjunath, (2002b).

Males: 0.000337(L-11) (B-11) (HT-11) +406.01

Brain weight in grams and cerebral index $(\mathrm{CI})$ were determined by the following formulas: brain weight $=$ cranial capacity X 1.035 .

Where 1.035 is the mass density of the brain (Courchesne et al., 2000; Frontera, 1958; Golalipour \& Hosseinpour, 2006).

Also index: "cerebral quotient $\left(\mathrm{cm}^{2}\right)=$ brain volume/height", was determined.

The data for each person was recorded on a special form and then analyzed by Epi6 and comparison of the means of anthropometric measurements by $T$ student Test $(\alpha=0.05)$ was used.

\section{RESULTS}

The Mean \pm SD of Head Length and width and also auricular height in Native Fars and Turkman groups are depicted in Table I so that Head Length and width in Turkmans were more than that of Native Fars males but auricular height in the former was less than the latter.

Brain weight was $1417.30 \pm 147.42 \mathrm{~g}$ and 1470.33 $\pm 88 \mathrm{~g}$ in Native Fars and Turkman males, respectively $(\mathrm{p}<0.05)$. The means \pm SD of cranial capacity was in Turkmans more than Native Fars males, significantly ( $\mathrm{p}<$ 0.05) (Table II).

Cerebral quotient was significantly higher in Turkmans (8.34) than Native Fars males (7.95); $(\mathrm{p}<0.05)$.

Table I. Cranial capacity, brain weight, head length and width and also auricular height in 17-20 years old Native Fars and Turkman males in Northern Iran.

\begin{tabular}{lll}
\hline parameter & $\begin{array}{l}\text { Native fars } \\
\text { Mean } \pm \text { SD }\end{array}$ & $\begin{array}{l}\text { Turkman } \\
\text { Mean } \pm \text { SD }\end{array}$ \\
\hline Head length $(\mathrm{mm})$ & $176.66 \pm 14.77$ & $186.95 \pm 7.12$ \\
Head width $(\mathrm{mm})$ & $149.35 \pm 10.65$ & $150.31 \pm 7.10$ \\
Auricular height $(\mathrm{mm})$ & $135.07 \pm 5.50$ & $133.79 \pm 5.69$ \\
\hline
\end{tabular}

Table II Cranial capacity, brain weight and cerebral index in 17-20 years old Native Fars and Turkman Males in Northern Iran.

\begin{tabular}{lcc}
\hline Parameter & $\begin{array}{c}\text { Native fars } \\
\text { mean } \pm \text { SD }\end{array}$ & $\begin{array}{c}\text { Turkman } \\
\text { mean } \pm \text { SD }\end{array}$ \\
\hline Cranial capacity $\left(\mathrm{cm}^{3}\right)$ & $1369.37 \pm 142.99$ & $1420.61 \pm 85.03$ \\
Brain weight $(\mathrm{g})$ & $1417.30 \pm 147.42$ & $1470.33 \pm 88.00$ \\
Cerebral index $(\%))$ & $3.40 \pm 0.37$ & $2.52 \pm 0.37$ \\
\hline
\end{tabular}

\section{DISCUSSION}

In this study, cranial capacity of the Turkman was higher than native Fars groups. Other researchers such as Manjunath (2002a), and Hwang et al. indicated cranial capacity in Indian, Korean male populations. Also Harvey et al. (1994) showed that 41 Africans and West Indians had a smaller average brain volume than that of 67 Caucasians.

In another study Morton (1849) using the method of measuring endocranial volume on 1000 skulls with packing material found that Blacks cranial capacity averaged about 5 in 3 less than Whites. More recently, 
Beals et al. (1984) carried out a large study on the endocranial volume, with measurements of up to 20,000 skulls from all around the world. He reported that East Asians, Europeans, and Africans averaged cranial volumes of 1415,1362 , and $1268 \mathrm{~cm}^{3}$ respectively and the skulls from East Asia were 3 in 3 larger than those from Europe, which in turn were 5 in 3 larger than those from Africa. Broca (1873) corroborated the Black-White difference using endocranial volume and also found that East Asians averaged larger cranial capacities than Whites.

Also in this study, brain weight of Turkman populations ( $1470.33 \mathrm{~g}$ ) was higher than native Fars males $(1417.30 \mathrm{~g})$ so that according to our findings, the brain weight was more than Nooranipoor and Masteri Farahani study results. In their study which was done on 32018 22 year-old males in Tehran, the center of Iran, the brain weight reported $1390.47 \mathrm{~g}$.

Also Hartman-Ramseir et al., (1994) reported that the mean brain weight was $1336 \mathrm{~g}$ in adult males with using brain autopsy method. On the other hand, Broca reported that Whites averaged heavier brains than Blacks with more complex convolutions and larger frontal lobes using the method of weighting brains at autopsy. Subsequent other studies have found an average BlackWhite difference of about $100 \mathrm{~g}$ (Bean, 1906; Mall, 1909; Pearl, 1934; Vint, 1934).

Furthermore, some studies have reported that the more White admixture (judged independently from skin color), the greater the average brain weight in Blacks (Bean; Mall; Pearl) and similarly Ho et al., (1980) determined in an autopsy study of 1261 American adults, that 811 White Americans averaged $1323 \mathrm{~g}$ and 450 Black Americans averaged $1223 \mathrm{~g}$, a difference of $100 \mathrm{~g}$. Since the Blacks and Whites of the study were similar in body size, differences in body size cannot explain away the differences in brain weight. The overall size of the human brain (determined by weight) differs by almost $30 \%$ among normal subjects (Pakkenberg \& Voigt, 1964; Dekaban.

In this study Cerebral quotient was 8.34 and 7.95 in Turkmans and Native Fars males, respectively which was higher than the findings of Nooranipooe \& Farahani's (2008) study (7.75).

Cerebral quotient $=$ brain volume/height", which can be useful for anthropometric and clinical applications and also the pattern of the relation of brain volume and height is less affected by gender in comparison with brain weight and body weight's relation, as well.
In addition, unlike body weight, height of an individual is not affected by being underweight, overweight, or obese (Nooranipoor \& Masteri Farahani).

Genetic and racial/ethnic characteristics and environmental factors can affect brain weight and cranial capacity. Regarding the genetic and racial/ethnic factor, anthropometric parameters such as cranial capacity have been shown to depend on gene expression (Okupe et al.,). In addition, different racial and ethnic groups may exhibit different patterns of gene expression. Therefore, Gene expression may be used as an important determining factor.

Several decades ago, Hooton (1926) reported that racial characteristics are best defined in the skull. Indeed, cranial capacity and subsequently brain weight constitutes one of the most important parameters for determining racial differences. Also, Okupe reported the higher fetal biparietal diameter in Nigerian than Europeans. Indeed, our previous studies revealed the important role of ethnicity in head dimentions (Golalipour et al.,;Golalipour \& Hosseinpour, 2006).

In conclusion this study showed that the ethnic factor can affect on brain weight and cranial capacity of 1720 years old Males in Northern Iran.

HAIDARI, K.; JAHANSHAHI, M. \& GOLALIPOUR, M. J. Diferencias étnicas en el peso del cerebro en hombres de 17 a 20 años de edad del norte de Irán. Int. J. Morphol., 34(3):986989, 2016.

RESUMEN: La capacidad craneal y el peso del cerebro son mediciones importantes en el estudio de las diferentes etnias. Se estimó el peso del cerebro y la capacidad craneal usando la fórmula lineal de Lee-Pearson, en 398 hombres de 17 a 20 años de edad (200 nativos Fars y 198 Turcomanos) en el norte de Irán. Las dimensiones de la cabeza se midieron con caliper deslizante y con una llave de Todd, para la medición auricular. La media \pm D.S. del peso del cerebro y la capacidad craneal en hom-

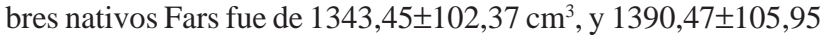
$\mathrm{g}$, y la de los turcomanos fue de $1163,02 \pm 115,76 \mathrm{~cm}^{3}$ y 1203,73 $\pm 119,81 \mathrm{~g}$, respectivamente. El índice cerebral fue de 3,40 $\pm 0,37$ $\%$ y $2,52 \pm 0,37 \%$ en nativos Fars y turcomanos, respectivamente, y el cociente cerebral fue mayor en los turcomanos $(8,34)$ que en los hombres Fars (7.95). Este estudio demostró que el efecto del factor étnico influye en el peso del cerebro en hombres de 17-20 años del norte de Irán.

PALABRAS CLAVE: Antropometría; Cefalometría; Peso del cerebro; Capacidad craneal; Índice cerebral; Cociente cerebral; Hombre; Irán. 


\section{REFERENCES}

Beals, K. L.; Smith, C. L. \& Dodd, S. M. Brain size, cranial morphology, climate, and time machines. Curr. Anthropol., 25(3):301-30, 1984.

Bean, R. B. Some racial peculiarities of the Negro brain. Am. J. Anat., 5(4):353432, 1906.

Broca, P. Sur les crânes de la caverne de l'Homme Mort (Loere). Rev. Anthropol., $2: 1-53,1873$.

Cotter, D.; Miszkiel, K.; Al-Sarraj, S.; Wilkinson, I. D.; Paley, M.; Harrison, M. J.; Hall-Craggs, M. A. \& Everall, I. P. The assessment of postmortem brain volume; a comparison of stereological and planimetric methodologies. Neuroradiology, 41(7):493-6, 1999.

Courchesne, E.; Chisum, H. J; Townsend, J.; Cowles, A.; Covington, J.; Egaas, B.; Harwood, M.; Hinds, S. \& Press, G. A. Normal brain development and aging: quantitative analysis at in vivo MR imaging in healthy volunteers. Radiology, 216(3):672-82, 2000.

Dekaban, A. S. Changes in brain weights during the span of human life: relation of brain weights to body heights and body weights. Ann. Neurol., 4(4):34556, 1978.

El-Feghi, I.; Sid-Ahmed, M. A. \& Ahmadi, M. Automatic localization of craniofacial landmarks for assisted cephalometry. Pattern Recognit., 37(3):609-21, 2004.

Frontera, J. G. Evaluation of the immediate effects of some fixatives upon the measurements of the brains of macaques. J. Comp. Neurol., 109(3):41738, 1958.

Golalipour, M. J.; Haidari, K.; Jahanshahi, M. \& Farahani, R. M. The shapes of head and face in normal male newborns in South-East of Caspian sea (Iran-Gorgan). J. Anat. Soc. India, 52(1):28-31, 2003.

Golalipour, M. J. \& Hosseinpour, K. R. Estimation of the cranial capacity and brain weight of Iranian female newborns. Eur. J. Anat., 10(2):49-52, 2006.

Grau, V.; Alcañiz, M.; Juan, M. C.; Monserrat, C. \& Knoll, C. Automatic localization of cephalometric Landmarks. J. Biomed. Inform., 34(3):14656,2001

Hartmann, P.; Ramseier, A.; Gudat, F.; Mihatsch, M. J. \& Polasek, W. Normal weight of the brain in adults in relation to age, sex, body height and weight. Pathologe, 15(3):165-70, 1994.

Harvey, I.; Persaud, R.; Ron, M. A.; Baker, G. \& Murray, R. M. Volumetric MRI measurements in bipolars compared with schizophrenics and healthy controls. Psychol. Med., 24(3):689-99, 1994.

Hooton, E. A. Methods of racial analysis. Science, 63(1621):75-81, 1926.

Ho, K. C.; Roessmann, U.; Straumfjord, J. V. \& Monroe, G. Analysis of brain weight. I. Adult brain weight in relation to sex, race, and age. Arch. Pathol. Lab. Med., 104(12):635-9, 1980.

Hwang, Y. I.; Lee, K. H.; Choi, B. Y.; Lee, K. S.; Lee, H. Y.; Sir, W. S.; Kim, H. J.; Koh, K. S.; Han, S. H. \& Chung, M. S. Study on the Korean adult cranial capacity. J. Korean Med. Sci., 10(4):239-42, 1995.

Irmak, M. K.; Korkmaz, A. \& Erogul, O. Selective brain cooling seems to be a mechanism leading to human craniofacial diversity observed in different geographical regions. Med. Hypotheses, 63(6):974-9, 2004.
Mall, F. P. On several anatomical characters of the human brain, said to vary according to race and sex, with especial reference to the weight of the frontal lobe. Am. J. Anat., 9(1):1-32, 1909.

Manjunath, K. Y. Estimation of cranial volume in dissecting room cadavers. $J$. Anat. Soc. India, 51(2):168-72, 2002a.

Manjunath, K. Y. Estimation of cranial volume - An overview of methodologies. J. Anat. Soc. India, 51(1):85-91, 2002b.

Mayhew, T. M. \& Olsen, D. R. Magnetic resonance imaging (MRI) and modelfree estimates of brain volume determined using the Cavalieri principle. J. Anat., 178:133-44, 1991.

Morton, S. G.(1849). Observations on the Size of the Brain in Various Races and Families of Man. Philadelphia, Proceedings of the Academy of Natural Sciences of Philadelphia, Volume 4, 1849. pp.221-4.

Nooranipoor, M. \& Farahani, R. M. Estimation of cranial capacity and brain weight in 18-22-year-old Iranian adults. Clin. Neurol. Neurosurg. 110(10):997-1002, 2008.

Okupe, R. F.; Coker, O. O. \& Gbajumo, S. A. Assessment of fetal biparietal diameter during normal pregnancy by ultrasound in Nigerian women. $B r$. J. Obstet. Gynecol., 91(7):629-32, 1984.

Pakkenberg, H. \& Voigt, J. Brain weight of the Danes. A forensic material. Acta Anat., 56(4):297-307, 1964

Pearl, R. The weight of the negro brain. Science, 80(2080):431-4, 1934.

Peters, M.; Jäncke, L. \& Zilles, K. Comparison of overall brain volume and midsagittal corpus callosum surface area as obtained from NMR scans and direct anatomical measures: a within-subject study on autopsy brains. Neuropsychologia, 38(10):1357-81, 2000

Svennerholm, L.; Boström, K. \& Jungbjer, B. Changes in weight and compositions of major membrane components of human brain during the span of adult human life of Swedes. Acta. Neuropathol., 94(4):345-52, 1997.

Vint, F. W. The brain of the Kenya native. J. Anat., 68(Pt. 2):216-23, 1934.

von Bonin, G. On the size of man's brain as indicated by skull capacity. $J$. Comp. Neurol., 59(1):1-28, 1934.

Williams, P. L. \& Bannister, L. H. Gray's Anatomy: The Anatomical Basis of Medicine and Surgery. $38^{\text {th }}$ ed. New York, Churchill Livingstone, 1995.

\section{Correspondence:}

Dr. Mohammad Jafar Golalipour

Gorgan Congenital Malformations Research Center

Department of Anatomical Sciences (Embryology and Histology)

Golestan University of Medical Sciences

P.O. Box: 49175-553

Gorgan - IRAN

E-mail: mjgolalipour@yahoo.com
Received:15-03.2016

Accepted:04-07-2016 